2001

\title{
PSYCHOANALYTIC PRAXIS AND THE TRUTH OF PAIN
}

William J. Richardson

Boston College, william.richardson@bc.edu

Follow this and additional works at: https://fordham.bepress.com/phil_research

Part of the Continental Philosophy Commons, French and Francophone Language and Literature Commons, Mental Disorders Commons, and the Other Psychiatry and Psychology Commons

\section{Recommended Citation}

Richardson, William J., "PSYCHOANALYTIC PRAXIS AND THE TRUTH OF PAIN" (2001). Research Resources. 19.

https://fordham.bepress.com/phil_research/19

This Article is brought to you for free and open access by the Hermeneutic and Phenomenological Philosophies of Science at DigitalResearch@Fordham. It has been accepted for inclusion in Research Resources by an authorized administrator of DigitalResearch@Fordham.

For more information, please contact considine@fordham.edu. 


\title{
WILLIAM J. RICHARDSON, S.J.
}

\section{PSYCHOANALYTIC PRAXIS AND THE TRUTH OF PAIN}

"The truth of pain is pain itself." - Anonymous

\begin{abstract}
Dear Patrick:
Another birthday - but a special one - good chance to think back over the years. I have warm memories of the time when we first met as graduate students in Louvain, stumbling through our first steps in phenomenology. Since then you have probed deeper and deeper into the hermeneutic approach to the philosophy of science. My own way has taken me from the initial reflection on Being and its truth in Heidegger to an exploration of the foundations of psychoanalysis, and now serendipitously, back to the problem of truth again. To salute you on the occasion, it seems appropriate to reflect briefly on the relation between science and truth as it is presented to me now in the work of the French psychoanalyst, Jacques Lacan, the so-called "French Freud." He spoke at different times and in different ways about both subjects but thematized the two together in a wellknown essay entitled, "Science and Truth." It is hardly a major landmark in his thought, but it can serve here as a convenient point of reference for this brief, unavoidably incomplete, reflection.
\end{abstract}

\section{SCIENCE}

Lacan's interest in science was in function of his effort to clarify in what way psychoanalysis can be considered a science. Clearly Freud wanted to qualify it as such, for this was the only way, he thought, to give his discovery of the unconscious intellectual respectability in the scientifico-cultural world of his time. The classical hypothetico-experimental methodology of nineteenth century science held for Freud an abiding fascination, and his ambition, initially at least, was to develop a theory of psychoanalysis that could approximate an analogous certitude. But the classic methodology rested on an epistemology that was positivistic in nature, where objects of research were essentially accessible through sense perception, and any contribution of the subject to the knowability of the object could be, in principle, disallowed by the rigor of procedure. For Lacan, however, the scientific paradigm of choice was not nineteenth century physics but twentieth century linguistics. Here, the role of the subject, especially when the method is applied to psychoanalysis, is inseparable from the research procedure itself, and the scientific character of the process must be conceived differently.

That difference was marked by the methodology of structuralism, to which Lacan was introduced by the work of Lévi-Strauss. Where natural science for Freud was "grounded" in a positivist (physically measurable, cause-effect) epistemology, the structuralist method was "grounded" for Lacan in the sheer formalism of the process:

B. E. Babich (ed..), Philosophy of Science, Van Gogh's Eyes, and God: Hermeneutic Essays in Honor of Patrick A. Heelan, S.J., 333-344.

(C) 2001 Kluwer Academic Publishers. Printed in the Netherlands. 
This is the problem of the grounding that must assure our discipline its place among the sciences: a problem of formalization. ...

Linguistics can serve us as a guide here, since that is the role it plays in the vanguard of contemporary anthropology . . . and the reduction of every language to the group of a very small number of these phonemic oppositions, by initiating an equally rigorous formalization of its highest morphemes, puts within our reach a precisely defined access to our own field. ${ }^{2}$

Lacan's espousal of this formalizing methodology as it occurs in Lévi-Strauss' work appears in the following:

It is clear that [Lévi-Strauss] ... can argue for a certain recuperation occurring in chemistry, owing to a physics of sapid and odorous qualities, otherwise stated, to a correlation between perceptual values and molecular architecture arrived at by means if a combinatory analysis, i.e., by a mathematics of the signifier, as has been the case in every science to date.

What's more, when, after having extracted the combinatory element in the elementary structures of kinshsip, [he] reports that a certain informer, to use the ethnologist's term, is himself fully capable of drawing the Lévi-Straussian graph, what is he telling us if not that, here again, he extracts the subject from the combinatory in question - the subject who on the graph has no other existence than the denotation ego?

It is the search for a comparable formalism that accounts for Lacan's always expanding effort to schematize, logicize, mathematicize and finally topologize his own speculative conceptualizations: "Mathematical formalization is our goal, our ideal. Why? Because it alone is matheme, i.e., it alone is capable of being integrally transmitted." 4 And all this was in the effort to make scientifically congenial, in terms, at least, of what he preferred to call "conjectural "science, the structuralist ideal that he adopted. ${ }^{5}$

Now this trajectory was made possible for Lacan by his conception of the subject of science, a conception that would serve likewise as model for the subject of psychanalysis. Both were born with the cogito of Descartes:

It is unthinkable that psychoanalysis as a practice and the Freudian unconscious as a discovery, could have taken on their roles before the birth in the century that has been called the century of genius, i.e., the seventeenth century - of [modern] science.... ${ }^{6}$

By this Lacan means that the unconscious Freud discovered has no meaning except with reference to consciousness as described in the Cartesian cogito.

Lacan makes his own Alexander Koyré's (1892-1964) account of the emergence of modern science: how mathematicization of the physical universe through the work of Copernicus, Kepler, Gallileo, \& Co., found its philosophical complement in the work of Descartes. Those familiar with Heidegger's critique of technology will recognize the similarity between Heidegger's interpretation of this event and Lacan's. The difference? Heidegger sees in it the birth of the subject-object dichotomy that then spawns scientific positivism with its fateful consequence in the guise of modern technology. Lacan is interested only in the structure of the subject itself that is at issue.

It is this subject, discovered through the cogito, that Lacan calls the "subjet of science." For him, it is as if the entire scientific enterprise - its history, its institutions and all the virulence of its burgeoning power - may be conceived as the function of a single hypostasized, egoless subject: the "correlate" of science as such, taken as a whole:

This correlate, as a moment, is the aftermath (défilé) of [Descartes'] rejection (rejet) of all knowledge [in the hyperbolic doubt], but is nevertheless claimed to establish for the subject a certain anchoring (amarrage) in being; I hold that this rejection of all knowledge constitutes the subject of science in its definition. ${ }^{7}$

Note that this subject is not the subject of limpid self-awareness that the ego of sum is often taken to be, for it includes the confounding obscurity of the unconscious that Freud discovered in it. Rather it is a subject, somehow anchored in "being," that remains after all "knowledge" has been rejected, like the empty field of what would 
eventually be called a mathesis universalis. The model for such a subject may be found in game theory, "which takes advantage of the thoroughly calculable character of a subject, strictly reduced to the formula for a matrix of signifying combinations." ${ }^{8}$ Such a subject is not the concrete, singular scientist who plays the game but the position of correlative subject that a given scientist occupies in the game.

Now this same egoless, disembodied subject, Lacan asserts, is the subject of psychoanalysis. Its depersonalized character is insisted upon to distinguish it from the subject with an identity all its own by reason of which it can assume "responsibility, "i.e., become an individual "responsible" subject. ${ }^{9}$ But how can such a subject be disengaged from Descartes' cogito? Lacan replies:

It is not vain to restate that in the [novelty] (l'épreuve) of writing I am thinking: "therefore I am" with quotes around the second clause, the notion is legible that thought only grounds being by knotting itself in speech where every operation goes right to the essence of language. ${ }^{10}$

I take him to mean that if the subject can say with certitude that "I am," the ground of that certitude is not in the thinking but in the saying of it. Descartes himself focuses on the thinking of the subject without adverting to the saying through which the illation comes to pass:

What about thinking? Here I make my discovery: thought exists; it alone cannot be separated from me. I am; I exist - this is certain. But for how long? For as long as I am thinking, for perhaps it could also come to pass that if I were to cease all thinking I would then utterly cease to exist. ${ }^{11}$

In all rigor, however, the illation from cogito to sum is valid not when thinking is taking place but when the subject says that it is taking place and in that sense implicitly affirms that it itself undeniably exists at that moment precisely in the saying. It is in this sense that "thought only grounds being by knotting itself in speech where every operation goes right to the essence of language." 12

The Cartesian subject for Lacan, then, is before all else a speaking subject, a subject of language. For that very reason it is the subject of the unconscious, for "the way opened up by Freud has no other meaning than the one I have made my own, namely that the unconscious is language" 13 Since the beginning of his public teaching (1953) Lacan has reiterated the thesis: "the unconscious is structured like a language."14

For the cognoscenti, then, the only thing new here is the force of Lacan's assertion: the unconscious is language, not simply "structured" by it.

The import of this remark is that the subject that enters psychoanalysis is not simply the singular human individual that requests it but essentially a "divided" subject. The sense is that the subject is split between a conscious level, dominated by the "ego," which, for, Lacan, is essentially an "imaginary" function as he understands that term, ${ }^{15}$ and an unconscious level that is subject to the laws of language operating through it, and comes to expression beyond control of the conscious ego. The latter he refers to most frequently not as the "unconscious of the subject" but as the "subject of the unconscious," i.e., the unconscious as subject, governed by the laws of language.

In explaining how the unconscious works, Lacan utilizes the distinction Saussure stresses between signifier (speech sound) and signified (concept represented by the sound). There is this difference in usage, however: for Saussure, the signifier refers directly to a signified, but for Lacan, the signifier refers rather to another signifier. The result is that a congeries of signifiers becomes a "signifying chain" that functions like "rings of a necklace that is a ring in another necklace made of rings." 16 And the subject? It is not to be identified with the chain of signifiers as such but rather as an effect of them, suspended from them as it were. "Conveyed (vehiculé) by a signifier in 
its relation to another signifier, the subject is to be rigorously distinguished from the biological individual as from the psychological evolution subsumable under the subject of understanding (comprehension) "17 And clearly the signifier must be distinguished from a sign:

Signs... represent something to someone....The register of the signifier is instituted in that a signi-fier represents a subject to another signifier. That is the structure of all unconscious formations: dreams, slips of the tongue, and puns. The same structure explains the subject's originary division. ${ }^{18}$

This is the subject that speaks through the analysand (sujet de l'énonciation) as distinct from the subject of the statement made by the analysand (sujet de l'énonce), which appears on the level of conscious self-awareness. ${ }^{19}$ How the signifying chain functions according to such basic laws of language as metonymy and metaphor, is too complex a story to be repeated here ${ }^{20}$ but it is such laws as these, taken in the ensemble, that govern the functioning of the unconscious.

For Lacan's disciples, all of this is old hat. He takes time to remind them only that in the seminar of the previous year, Crucial Problems for Psychoanalysis (1964-1965), he had laid stress on the momentary (ponctuel), pulsating, peek-a-boo way in which the unconscious irrupts in consciousness. But what sense does it make to say that "the subject on which we operate in psychoanalysis can only be the subject of science" ${ }^{21}$ Surely the subject is always instantiated in a singular analysand, designated by a name and marked by all the modalities of identification that go with it. I take Lacan to mean that the basic structure of the unconscious as delineated above prescinds from any singularizing factors and is transindividual, quasi-absolute in nature (like the subject of game theory), the way the subject of science is a position that functions independently of the concrete activity of any individual scientist. This, at any rate, is how I understand the "thoroughly calculable character of a subject [as] strictly reduced to the formula for a matrix of signifying combinations."

Once this much is said, little more is offered explicitly here to clarify Lacan's conception of science. He does remark, however, that everything so far concerns the subject of science but nothing has been said about its object, a matter that has "remained unelucidated since the birth of science." 22 As for the "object" of psychoanalysis, Lacan has already spoken of it as object a (what for Freud was the "lost," i.e. no longer present, "object" of the subject's fundamental quest. ${ }^{23}$ As "lost," this object is irretrievable; as "cause of desire" (Lacan's formula), it is unattainble. The subject itself (of science as well as of psychoanalysis), then, is marked by an irreparable lack/absence/hole that scars its structure with an ineluctable negativity. If all this characterizes the object of psychoanalysis, surely "the object of science as such will be thereby modified" 24 - but Lacan doesn't take the matter any further here.

\section{TRUTH}

In the aerie of Lacanian theory what has been said up to now is fairly straightforward.

But what can "truth" mean for a subject of this kind? The question for Freud was much simpler than for Lacan. In his New Introductory Lectures on Psychoanalysis he characterizes "scientific thinking" as follows:

Its endeavor is to arrive at correspondence with reality - that is to say with what exists outside us and independently of us and, as experience has taught us, is decisive for the fulfillment or disap-pointment of our wishes. This correspondence with the real external world we call "truth." 
It re-mains the aim of scientific work even if we leave the practical value of that work out of account. ${ }^{25}$

As for the truth of psychoanalysis, Freud would probably add nuance to the term "reality" with his distinction between "psychical" and "material" reality ${ }^{26}$ but his method would still be analogous to that of natural science, i.e., to search out the causes at play in any given phenomenon under investigation. Evidence for this appears in the frequency with which he refers to his endeavor, especially in the early years, as an "aetiology," a science (-logos) of causes (aitia-). ${ }^{27}$ But all this is the language of classical positivism, where truth consists in correspondence between a subject's judgment and an object judged. ${ }^{28}$ What happens to truth in psychoanalysis when the positivist ideal is rejected out of hand?

By the time Lacan broaches the question of truth in "Science and Truth," there is a considerable backlog of his remarks on the subject that he can presume his listeners have in mind. In the early years of his teaching he made much of the distinction between "empty" speech and "full" speech: "empty speech takes place when the subject seems to be talking in vain about someone who, even if he were his spitting image, can never become one with the assumption of his desire", ${ }^{29}$ "full" speech is achieved not by examination of the "here and now," nor by the examination of resistances, but by anamnesis:

In psychoanalytic anamnesis it is not a question of reality, but of truth, because the effect of full speech is to reorder past contingencies by conferring on them the sense of necessities to come, such as they are constituted by the little freedom through which the subject makes them present. ${ }^{30} \ldots$ It is certainly this assumption of his history by the subject, in so far as it is constituted by the speech addressed to the other, that constitutes the ground of the new method that Freud called psychoanalysis. . . ${ }^{31}$

The truth of the subject comes about, then, through the speaking that constitutes the psychoanalytic process. It is not based on any kind of correspondence; it is essentially revelatory in nature and takes place when meaning (sens) is discovered in an historicizing process. It has no other foundation than the efficacy of the language that utters it and prescinds completely from the "reality" that characterizes the world of its conscious activity. Founded thus in language itself, truth has an inexhaustible resilience: "Even if [language] communicates nothing, the discourse represents the existence of communication; even if it denies the evidence, it affirms that speech constitutes truth; even if it is intended to deceive, the discourse speculates on faith in testimony." 32

There is another element in Lacan's backlog: the negatived nature of truth. As early as 1955 in "The Freudian Thing," a paper commemorating in Vienna the centenary of Freud's birth, Lacan delivered a grotesque prosopopeia in the name of truth to the evident consternation of his audience. "Men, listen, I am giving you the secret. I, Truth, will speak" His point is that there is no such thing as total truth - especially in psychoanalysis - and truth arrives at best as damaged goods. Eventually he will claim that no truth can ever be whole. ${ }^{33}$ Here, however, he underlines not simply the manifestation but the inevitable distortion of truth as it comes to expression:

For you I am the enigma of her who vanishes as soon as she appears. . . The discourse of error, its articulation in acts, could bear witness to the truth against evidence itself. . . For the most innocent intention is disconcerted at being unable to conceal the fact that one's unsuccessful acts are the most successful and that one's failure fulfills one's most secret wish. . . I wander about in what you regard as being the least true in essence: in the dream, in the way the nost farfetched conceit, the most grotesque nonsense of the joke defies sense, in chance, not in its law, but in its contingence, and I never do more to change the face of the world than when I give it the profile of Cleopatra's nose. ${ }^{34}$ 
Truth, then, carries the scars of negativity. In other words: "Error is the habitual incarnation of truth. ...Error is the usual manifestation of the truth itself - so that the paths of truth are in essence the paths of error." ${ }^{35}$ Clearly, any complete account of truth must also account for the error and distortion (i.e., non-truth) that infiltrate it.

\section{TRUTH AND CAUSE}

The most curious element of this essay is Lacan's proposal to consider truth as cause. One can think in these terms for Freud, perhaps, since, positivist that he was, he could well say that the discovery of the patient's truth (e.g., in "Little Hans" or the "Rat Man") "caused" a relief of symptoms. One might even use this language for the early Lacan, insofar as the achievement of "full" speech would, in principle, cause the liberation of a patient, at least partially, from her neurosis. But what does it mean here?

The medium which will serve us at this point is one I brought up earlier. It is the cause: not the cause as logical category, but as causing the whole efffect. Will you psychoanalysts refuse to take on the question of the truth as cause when your very careers are built upon it? ${ }^{36}$

What in fact is Lacan trying to say beyond playing with the ambiguity of "cause"? He argues by comparison with other disciplines where truth allegedly also functions as cause: magic, religion and science. He manages this by introducing Aristotle's language about the four causes, though Aristotle himself might be startled by this allegation of paternity. Be that as it may, for Lacan: in magic, truth functions as efficient cause; in religion, as final cause; in science, as formal cause and in psychoanalysis as material cause. None of this is self-evident; still less is it satisfactorily argued. For example: what can it mean to say that truth as cause in psychoanalysis comes under the guise of material cause, because of "the form of impact (incidence) of the signifier" that Lacan ascribes to it ${ }^{37}$ One can argue, perhaps, that psychoanalysis , through the" impact of the signifier," which (like the whole of language) Lacan takes to be "material" in nature, exercises a kind of "material" causality, but the symbolic order as such is certainly "formal" in nature. And if science functions as "formal" cause, how does the "formal" causality of science differ from theat of the symbolic order as such, which must be identified with language as "material" cause? Finally, if we take truth as formal cause (science) and truth as material cause (psychoanalysis) on the most superficial level, what is the effect of this reciprocal causality? Is it truth as such, causing itself to be true? What, then, makes it true? What is truth itself? Lacan's thought leaves us to our hunger here. ${ }^{38}$

$$
* * *
$$

How does one evaluate "Science and Truth" as a contribution to the evolution of Lacan's thought at this period of its development? Anything thorough would have to address the heart of he matter: the identification (here) of the subject of psychoanalysis and the subject of science. But that would make for a long day at the office. More tractable is to comment on Lacan's conception of truth in the essay, but even here logistic restrictions make it impossible to do more than sketch the bare essentials of a critique. I shall confine my remarks to three: 1) concerning the fundamental nature of truth; 2) concerning the relation between truth and language; 3 ) concerning one fundamental difficulty that must be addressed.

1. Lacan's conception of truth in the essay, to the extent that it leaves the achievements of the savoir of science beyond its ken, I find deeply flawed. Scientific 
method, whatever its rigor, is not an end in itself but the means of discovering the way things are in the world of human experience. The first ingredient of a viable conception of truth must be the dis-covering of what is the case. More radically, Lacan cites with approval but without elaboration the gnome of a contemporary philosopher whom he leaves nameless: "the truth of pain is pain itself." 39 I take this to mean that the truth of pain is not in a judgment about it but in the simple fact that it is what it is and "makes itself seen," i.e., "evident" as such. ${ }^{40} \mathrm{My}$ claim is that e-vidence in its most radical sense of making (letting) itself be seen is the fundamental nature of truth from which all other versions of it derive. Any version of truth (e.g., concordance, coherence) is secondary to the originary manifestation of what is in fact the case. I submit that this is the most plausible way to explain the truth revealed by the structuralist method of Lévi-Strauss that Lacan cites with approval, the "corrrelation between perceptual values and molecular architecture arrived at by means of combinatory analysis, i.e., by the mathematics of the signifier." 41 The e-vidence (truth) is in the sheer manifestation of the correlation as index of the way things are.

Obviously the notion of originary truth as e-vidence/dis-covery/dis-closure/selfmanifestation recalls Heidegger's thematizing of the Greek word for truth, a-letheia: a combination of -lêthê (what lies hidden in concealment) and $a$-, the alpha prefix indicating privation. Taken together, they identify truth as non-concealment, or revelation. Of course Lacan was aw are of Heidegger's conception of truth and apparently was quite comfortable with it in 1953 when describing the psychoanalytic process: "In psychoanalytic anamnesis it is not a question of reality, but of truth, because the effect of full speech is to reorder past contingencies by conferring on them the sense of necessities to come, such as they are constituted by the little freedom through which the subject makes them present." ${ }^{2}$ Apparently he lost interest in the conception as he turned more and more toward the formalism of Lévi-Struss to develop the "scientific" character of psychoanalysis.

What Heidegger adds to the conception of truth as e-vidence (dis-covery) is a frequent reflection on the negative component of truth, lethe. The negativity in question is not simply an absence of mnifestation but includes a dynamic quality that Heidegger articulates especially in the essay, "On the Essence of Truth." There, after showing that truth as correspondence is made possible by a prior openness (what I have been calling "e-vidence," etc.) between knower and known prior to, and enabling, the judgment of correspondence, he asserts that no account of the essence of truth is complete without a parallel analysis of a corresponding "non-truth," since no re-velation in a finite world can be total, i.e., "whole" (pas toute). This non-essence of truth takes two forms: mystery (Geheimnis), the concealment of what still remains unrevealed, and errancy (Irre), a compounding in forgetfulness of this double concealment:

Errancy is the essential counteressence to the originary essence of truth. Errancy opens itself up as the open region for every counterplay to essential truth. Errancy is the open site for, and ground of, error. Error is not merely an isolated mistake but the kingdom (the dominion) of the history of those entanglements in which all kinds of erring get interwoven. In conformity with its openness and its relatedness to beings as a whole, every mode of comportment has its manner of erring. Error "extends from the most ordinary wasting of time, making a mistake, and mis-calculating, to going astray and venturing too far in one's essential attitudes and decisions. . . By leading them astray, errancy dominates human beings through and through." 43 
My suggestion is that this conception of a non-essence (i.e., negativity) ingredient to the essence of truth is comprehensive enough to make room for the hypostasized Truth of the famous prospopeia as well as for the residual distortions and lies that contaminate truth. This certainly would account for the fact that no truth can be "whole" (pas toute). And if we go this far, may we not have a suggestive reading of the following passage:

This lack of truth about truth, necessitating as it does all the traps meta-language - as sham and logic - falls into, is the true place of Urverdrängung, i.e., of primal repression which draws towards it every other repression. ${ }^{44}$

To claim a correlation between lêthê for Heidegger and "repression" for Lacan (here even "primary" repression) would be a daring move. But if it worked, we might go one step further and ask if there might not be a discernible similarity between lêthê (Heidegger) and the real (Lacan)? If so, the next question would be to ask if the event of a-lêtheia (privation of lêthê) might not be thought as the event in which the World, through the functioning of symbolic and imaginary, were constituted. But none of these extensions is necessary for Lacanians to find in Heidegger's experience of $a$-lêtheia the valuable philosophic support for Lacan's experience of truth in psychoanalysis, of which he is in need.

Be that as it may, does an aletheic conception of truth offer us a way of thinking truth as cause? As a matter of fact, Heidegger does suggest that Aristotle's four causes combine to constitute a process of revelation. To clarify the notion of techne, he writes:

Technê is a mode of alêtheuein. It reveals whatever does not bring itself forth and does not yet lie here before us, whatever can look and turn out now one way and now another. Whoever builds a house ... reveals what is to be brought forth, according to the perspectives of the four modes of occasioning. This revealing gathers together in advance the aspect and the matter of house ... with a view to the finished thing envisioned as completed, and from this gathering determines the manner of its construction. Thus what is decisive in technê does not lie at all in making and manipulating nor in the using of means, but rather in the aforementioned revealing. It is as revealing, and not as manufacturing, that techne is a bringing forth. ${ }^{45}$

Aristotle's four causes coalesce, then, in a process of revelation. If this revelatory coalescence be conceived as "cause," what would be its "effect"? Using language as loosely as Lacan does, may we not say that the "effect" of alêtheia is freedom - not in any voluntaristic sense, of course, but simply as a liberation from the constraint of darkness (lêthê)? More precisely, the effect of a successful analysis would be the experience of freedom that comes to an analysand through the dis-covery that "Thou art that," the moment when "the real journey begins." 46 "The truth of pain is pain itself.

2. Lacan insists on one more point, the close correlation between truth and language: "since the truth is grounded in the fact that it speaks, . . . [it] has no other means by which to do so." 47 For Heidegger, this correlation is based upon his interpretation of the meaning of $\log o s$ for the early Greeks, as may be seen, for example, in the work of Heraclitus. ${ }^{48}$ Although logos from early on was associated with speech, the original sense of it for Heraclitus came from legein, meaning "to gather" (as one gathers wood), or "to bring together" into some kind of unity that thereby becomes manifest as what it is. Like physis, logos was from the beginning associated with the coming to pass of $a$-lêtheia, the unconcealment of everything that is. The task of human beings would be to collaborate with the process by letting beings be seen as what they are. Eventually, it became possible to think of this gathering process (the coming-to-pass of truth) as originary Language and the task of human beings as bringing it to expression in words. Heidegger does not argue that Heraclitus saw this 
clearly himself but claims rather to be articulating what Heraclitus left unsaid yet somehow inscribed in the language he used. At any rate, the vocation of human beings as such would be to bring to articulation the language of Logos as process of Aletheia, a task for which the poets serve as models. ${ }^{49}$

Transposed into the context of Lacanian psychoanalysis, this would mean, I suggest, that "truth is grounded in the fact that it speaks," because a-lêtheia comes-topass through the logos operating in the very action through which the analysand achieves full speech. "It has no other means with which to do so. "

3. BUT all this founders on the irreducible fact that "there is no Other of the Other," and Being/A-lêtheia/Logos must certainly be considered as Other than the language of psychoanalysis - or so the objection goes. I have dealt with this issue at length elsewhere ${ }^{50}$ and shall recall briefly only what is relevant to the present context. When Lacan speaks of Being, he refers to it as some kind of substance:

There is no metalanguage. When I say that, that means apparently no language of Being. But is there Being? ... Being is, as they say and Non-being is not.... This Being can be supposed only for certain words - individual, for example, or substance. ${ }^{51}$

But is the Being Heidegger speaks of a "substance"? No way! It is neither a substance nor any other kind of thing that "is"- the classic analysis in Being and Time reveals it precisely as "No-thing" (Nichts). ${ }^{52}$ In no way can it be considered a metalanguage - a language that "is" beyond language. Rather than something that "is," Being/Logos is the process by which everythiug that "is" is let be what it is, thus showing itself (becoming e-vident) as what it is and functioning as such.. Profoundly different from whatever "is," Being lets everything that is be present, manifesting itself as what it is and able to function as such.

A case in point: In Seminar XX. 1972-1973. Encore, Lacan distinguishes between existence and existence, and Fink elucidates the difference:

In Lacan's terminology, existence is a product of language: language brings things into existence (makes them part of human reality), things which had no existence prior to being ciphered, symbolized, or put into words.

The real, therefore, does not exist, since it precedes language; Lacan reserves a separate word for it, . . . it "ex-sists." It exists outside of or apart from our reality. Obviously, insofar as we name and talk about the Real and weave it into a theoretical discourse on language and the "time before the word,"

we draw it into language and thereby give a kind of existence to that which, in its very concept,

has only ex-sistence." ${ }^{\prime 3}$

But whether Lacan speaks of existence or ex-sistence, each one is what it is as different from the other in order to mean anything at all. What lets them be manifest as what they are, precisely in their differentiation from one another - this is what Heidegger understands by Being. Without something of the sort, Lacan's entire speculation, I submit, lacks the philosophial warrant of which it is in need.

$$
* * *
$$

To conclude: once Lacan identifies the subject of psychoanalysis with the subject of science, obscurities persist with regard to the analogy between the respective modes of savoir to be found in each discipline when one considers their respective relation to truth. Surely truth must be allowed a place in science beyond the ken of the sheer methodology of exactitude, but as to how that truth is to be conceived so as to be discoverable in both science and psychoanalysis (in however analogous a fashion) must remain for now an open question. In 1965, Lacan leaves us completely in the dark. The 
hypothesis ventured here is that a conception of truth as evidence/dis-closure - in short as alêtheia for Heidegger (including the non-truth that this comports) goes a long way toward satisfying Lacan's need for such a concept. How much further can it go? For now that must remain to be seen.

Boston College

\section{NOTES}

1 Jacques Lacan, "Science and Truth," trans. B. Fink News Letter of the. Freudian Field, 1 (1989): 429/855-77. The essay, published separately in Ecrits $(1966,855-77)$, was the opening lecture of Le Seminaire.Livre XIII. L'objet de la psychanalyse (1965-1966) (unpublished).

2 Lacan, Écrits. A Selection, trans. A. Sheridan (New York: W. W. Norton, 1977).

3 Lacan, "Science and Truth," 10.

4 The Seminaire of Jacques Lacan. Book XX (1972-1973). On Feminine Sexuality, the Limits of Love and Knowledge. J.-A. Miller, ed., B. Fink, trans. (New York: W.W. Norton, 1998), 119.

5 Lacan prefers to call Dilthey's Geisteswissenschaften "conjectural" rather than "humane" or"social" sciences because "conjectural" allows the suggestion of exact calculability (in terms, at least, of probability theory), whereas "human" and "social" leave room for an anthropocentric humanism that he repudiates. The term allows a closer approximation of "conjectural" science to "exact" science: "The opposition between exact sciences and conjectural sciences is no longer sustainable once conjecture is subject to exact calculation (using probability) and exactness is merely grounded in a formalism separating axioms from laws for grouping symbols" (1989 11). Psychoanalysis would be just such a conjectural science.

6 Ibid., 6.

7 Ibid., 5.

8 Ibid, 9

9 Ibid., 11

${ }^{10}$ Ibid., 13 .

11 R. Descartes, Discourse on Method and Meditations on First Philosophy, trans., D. A. Cress (Indianapolis: Hackett, 1998), 65.

12 Lacan, "Science and Truth," 13.

13 Ibid., 13.

14 Explanations of this thesis abound: e.g., B. Fink, The Lacanian Subject. Between Language and Jouissance. (Princeton: Princeton University Press, 1995); J. S. Lee, Jacques Lacan (Boston: Twayne, 1990); J. Dor, Introduction to the Reading of Lacan. The Unconscious Structured Like a Language. J. F. Gurewich and S. Fairfield, eds., (Northvale, N.J. and London: Jason Aronson, 1997); J. P. Muller and W.J. Richardson, Lacan and Language. A Reader's Guide to the Ecrits (New York: W. W. Norton, 1983), 1-25.

15 The "ego" for Lacan is essentially a unified image, perceived as if reflected in a mirror embodied in some other that gathers into unity the still disordered elements of the becoming subject (Écrits, 1-7).

16 Lacan, Écrits, 153

17 Lacan, "Science and Truth," 23.

18 Lacan, "Position of the Unconscious," trans. Bruce Fink in Fink, M. Jaanus, R. Feldstein, eds., Reading Seminar XI. Lacan's Four Fundamental Concepts of Psychoanalysis (Albany: State University of New York Press, 1995), 269

19 Leupin notes that when Lacan rewrites Descartes' cogito as I think, "therefore I am" as cited above, he intends to underline the the division between the (speaking) "subject of the enunciation" and the (spoken) "subject of the enunciated." A. Leupin, "Introduction," Leupin, ed., Lacan and the Human Sciences Lincoln: University of Nebraska Press, 1991) 20, n. 4.

20 R. Grigg, "Metaphor and Metonymy," Newsletter of the Freudian Field, 3 (1989): 59-79.

21 Lacan, "Science and Truth," 7.

${ }^{22}$ Ibid., 12.

23 S. Freud, Negation [1925] in Standard Edition of the Complete Psychological Works of Sigmund Freud. Trans. and ed. J. Strachey et al. (London: Hogarth Press, 1966-74), S.E. 19, 237.

${ }^{24}$ Lacan, "Science and Truth," 12.

25 Freud, New Introductory Lectures on Psychoanalysis, S.E. 22 [1932], 170

26 Freud, The Interpretation of Dreams, S.E. 4 and 5 [1900], 620. 
27 For example: "On the Grounds for Detaching a Particular Syndrome under the DescriptionAnxiety Neurosis. Incidence and Aetiology of Anxiety Neurosis" (1895; "Obsessions and Phobias: Their Psychical Mechanism and Their Aetiology" ( (1895); "Heredity and the Aetiology of the Neuroses" (1896); "Further Remarks on the Neuropsychoses of Defence. The Specific Aetiology of Hysteria" (1896); "The Aetiology of Hysteria" (1896); "Sexuality in the Aetiology of the Neuroses" (1896); "My Views on the Part Played by Sexuality in the Aetiology of the Neuroses" (1906); Introductury Lectures on Psychoanalysis. General Theory of the Neuroses. Some thoughts on Elements and Regression - Aetiology (1916), etc.

28 For a succinct analysis of the nature of truth both as correspondence and coherence, and each as distinct from meaning, see M. Cavell, The Psychoanalytic Mind: From Freud to Philosophy (Cambridge: Harvard University Press), 17-18.

29 Écrits, 45.

30 Ibid., 48 .

31 Ibid.

32 Écrits, 43.

33 On Feminine Sexuality, the Limits of Love and Knowledge, 92.

34 Écrits, 121-122.

35 Lacan, The Seminar of Jacques Lacan. Book l. Freud's Papers on Technique. 1953-1954. Ed. J.A. Miller. J. Forrester, trans. (New York: W.W. Norton, 1988), 263/289.

36 "Science and Truth," 17. The word "cause," to begin with, is highly ambiguous, and Lacan makes much of this ambiguity. Bowie summarizes: "Lacan toys relentlessly with a single pun, on the word cause: the unconscious is the cause of truth (causes it, makes it happen) and analysis has soleresponsibility for defending truth's cause (its interests, its standing). This piece of word-play is confidently executed, and has the support of etymology: the Latin causa had both senses and also, for that matter, gave birth to the thing (chose) so elaborately played upon in "The Freudian Thing." But does the pun portray or disguise its own incoherence? The two senses of cause can scarcely have equivalent and co-active roles in he causerie of psychoanalysis.” M. Bowie, Lacan (Cambridge: Harvard University Press, 1991), 119.

37 "Science and Truth," 22.

38 See "Science and Truth," 23.

39 Ibid., 18. Who the philosopheer was is a matter of conjecture. Fink ("Jacques Lacan, 'Science and Truth."' News Letter of the Freudian Field 1 \& 2 [1989]: 4-29; 28) suggests Merleau-Ponty, but Dany Nobus, in a private communication, notes that Merleau-Ponty died in 1960, five years earlier, and could hardly be referred to as "a philosopher [recently] awarded full academic honors."

${ }^{40}$ The Oxford Dictionary of English Etymology notes "evident" from the Latin $e$-videre as having originally the sense of the middle voice as "making itself seen." At the risk of annoying the reader I shall hereafter hyphenate the word "e-vidence" to emphasize the middle voice sense in which I am using it.

41 "Science and Truth," 10

42 Écrits, 48.

43 M. Heidegger, "On the Essence of Truth,” D.F. Krell, ed., Basic Writings, (San Francisco: Harper \& Row, 1993), 134

44 "Science and Truth," 16

45 M. Heidegger, "The Age of the World as Picture," The Question Concerning Technology and Other Essays. Trans. and ed. W.Lovitt (New York: Harper \& Row, 1977), 13.

46 Écrits, 7.

47 "Science and Truth," 16.

48 Heidegger, "Logos (Heraclitus Fragment B50) in Early Greek Thinking, trans. D. F. Krell (New York: Harper \& Row, 1975), 59-78.

49 It should be noted that Lacan personally translated this article into French (1956).

50 W.J.Richardson, "Psychoanalysis and the Being-Question" in J.H.Smith \& W. Kerrigan, eds., Interpreting Lacan. (New Haven: Yale University Press, 1983); "Heidegger Among the Doctors" in J. Sallis, ed., Reading Heidegger. Commemorations (Chicago: University of Chicago Press, 1990); "La vérité dans la psychanalyse" in R. Major et al., eds., Lacan avec les Philosophes. Bibliothèque du College international de philosophie (Paris: Albin Michel, 1991).

51 On Feminine Sexuality, the Limits of Love and Knowledge, 118.

52 Heidegger, Being and Time, trans. J. Macquarrie and E. Robinson (London: SCM Press, 1962), 228-235.

53 Fink, The Lacanian Subject: Between Language and Jouissance (Princeton: Princeton University Press, 1995), 25. 